\title{
Gregarine Cephaloidophora communis Mawrodiadi, 1908 in the Barnacle Euraphia rhyzophorae, Oliveira, 1940 from Brazil
}

\author{
Dyrce Lacombe/ ${ }^{+}$, Sophie Jakowska*, Edalton Silva/ ${ }^{++}$ \\ Departamento de Entomologia, Instituto Oswaldo Cruz-Fiocruz. Estrada da Covanca 56, 22735-200 Rio de Janeiro, RJ, Brasil \\ *Department of Biological Sciences, College of Staten Island, City University of NewYork, New York, USA
}

The gregarine Cephaloidophora communis was observed for the first time in Brazil in the barnacles Euraphia rhyzophorae collected in Angra dos Reis, Rio de Janeiro, Brazil, between 1990 and 1996. Histological studies showed growth phases of the parasite in specific parts of the digestive system. The intracellular forms occurred in the vacuoles of the intestinal cells. Syzygy was frequent, and the most common form following syzygy was cylindrical, with a single membrane. The cytoplasm of the gregarines was always irregular, dense, and occasionally presenting a dark stoch area.

Key words: Cephaloidophora communis - gregarines - barnacles - histology - digestive tube - Brazil

The gregarines were arranged in the traditional phylum Sporozoa, renamed Apicomplexa by Levine (1970). They are parasitic protoctists, all endoparasites of invertebrate or vertebrate hosts. They show different degrees of host specificity (Vivier \& Desportes 1989).

Dusznski (in Vivier \& Desportes 1989) estimates that there are about 500 species in the class Gregarinia. The wide majority of gregarines are monoxenous, but some species may be heteroxenous because their life cycles are still unknown.

Gregarines in the intestine of barnacles were first reported by Kölliker (1848), and described in the intestine of Balanus pallidus as Gregarina balani.

Mawrodiadi (1908) demonstrated C. communis in $B$. eburneus, B. amphitrite, B. crenatus and Megabalanus tintinnabulum.

Tregouboff (1912) and Kamm (1922) pointed out that the members of the family Cephaloidophoridae are parasites of crustaceans and develop within the cells, producing one or more oval spores. Ball (1973) and Henry (1938) also studied gregarines in barnacles. Tuzet and Ormières (1964) contributed to their morphology and Barnes (1953) to the developmental physiology of barnacle larvae and their gregarines. Reger (1966) and Reger et al. (1967) studied the spores of $C$. communis in the cells of the intestine of M. tintinnabulum using electron microscopy.

Arvy and Nigrelli (1969), reported the gregarines in intestine of B. nubilis and B. eburneus collected on Coney Island, New York, near the Osborn Laboratory of Marine Science.

${ }^{+}$Corresponding author. Fax: +55-21-3392.1216. E-mail: dlacombe@bol.com.br

${ }^{++}$Post graduation student in Animal Biology of Universidade Federal Rural do Rio de Janeiro, Seropédica, RJ, Brasil

Received 19 December 2001

Accepted 5 June 2002
Gregarines in barnacles have been studied by various authors in the United States of America, England, France and Germany. In Brazil there has been relatively little interest in these sessile crustaceans. Since, this is the first report of gregarine in the intestine of the barnacle Euraphia rhyzophorae, Oliveira (1940) collected on the shore in Angra dos Reis, near the city of Rio de Janeiro.

\section{MATERIALS AND METHODS}

Approximately 150 adult barnacles of E. rhyzophorae were collected from the roots of Rhyzophora mangle on the shore in Angra dos Reis, State of Rio de Janeiro, Brazil, between 1990 and 1996.

The barnacles, with or without substrate, were immediately immersed in a fixative such as Bouin's (according to Duboscq-Brasil) or Heidenhein's original of Susa.

In the laboratory the specimens were separated for anatomical, microanatomical and histological studies. Dehydrated in alcohol-benzol series, they were embedded in "histoseck" paraffin. Serial sections cut at 5 and 7 $\mu \mathrm{m}$ were stained with Gallocyanin, Chromotrop 2R, Heidenhain Iron Hematoxylin and Mallory Hematoxylin, following the methods presented by Pinto (1919), Romein (1928), Henry (1938), Pantin (1948), Barth (1953) and Pearse (1960).

\section{RESULTS AND DISCUSSION}

C. communis gregarines were observed in the mid and hind gut of the barnacles E. rhyzophorae (Fig. 1, GR, INT). This species of gregarine was described by Mawrodiadi (1908) from other species of barnacles: B. improvisus, $B$. amphitrite, B. eburneus and M. tintinnabulum, in which oval spores 50 to $60 \mu \mathrm{m}$ in size were observed inside. In gregarines of the family Cephaloiphoridae these organisms can be seen associated during their growth in groups of usually two individuals, or may develop singly (Fig. 1), as reported by Vivier and Desportes (1989).

The gregarines in E. rhyzophorae were always numerous in the digestive tube and exhibited different growth phases. Although almost all organs of the host may be infected by apicomplexan zoites or other forms, there is always a motile stage that may penetrate the target or- 
gans, where the development may be completed (Vivier \& Desportes 1989).

Fig. 1 shows deuteromites (GR) containing dark round bodies (MR) of stock material in the lumen of the midgut (INT). NU identifies the nucleus of one of
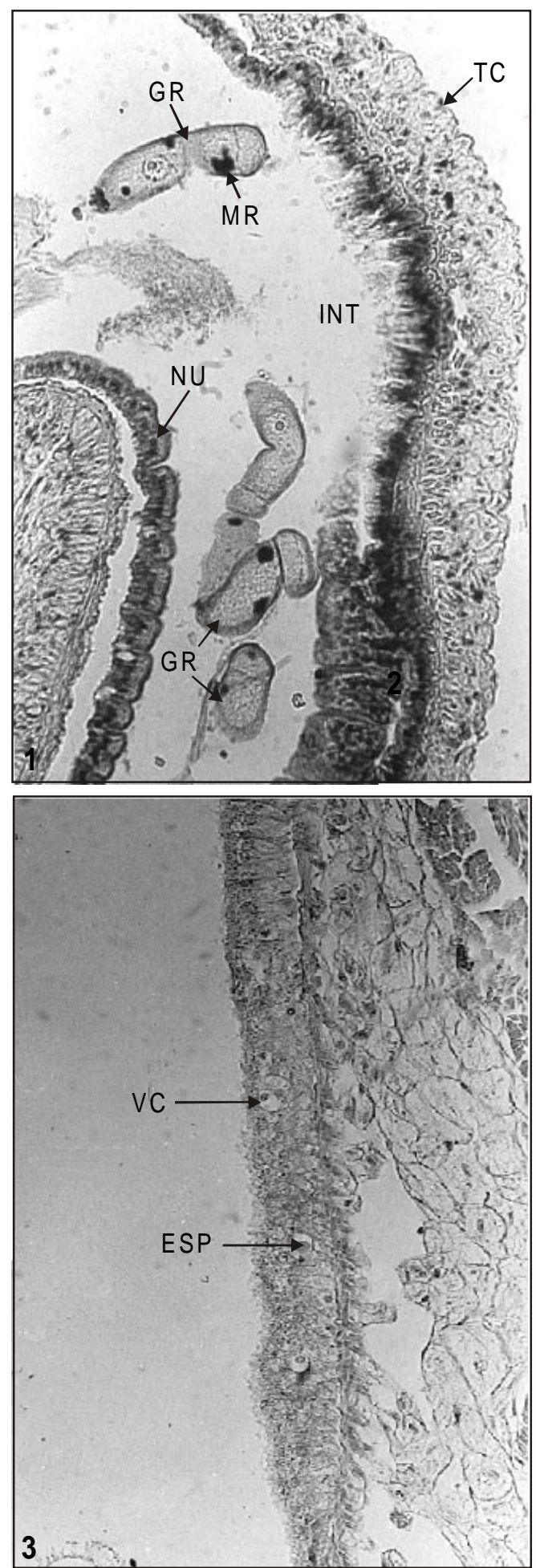

the epithelial cells.

The forms seen next to the epithelial cells (Fig. 2 EP) are limited to the plasma membrane that lines the intestinal lumen. The epithelial wall of the intestine in barnacles has extended narrow cells. Their cytoplasm is dense, with
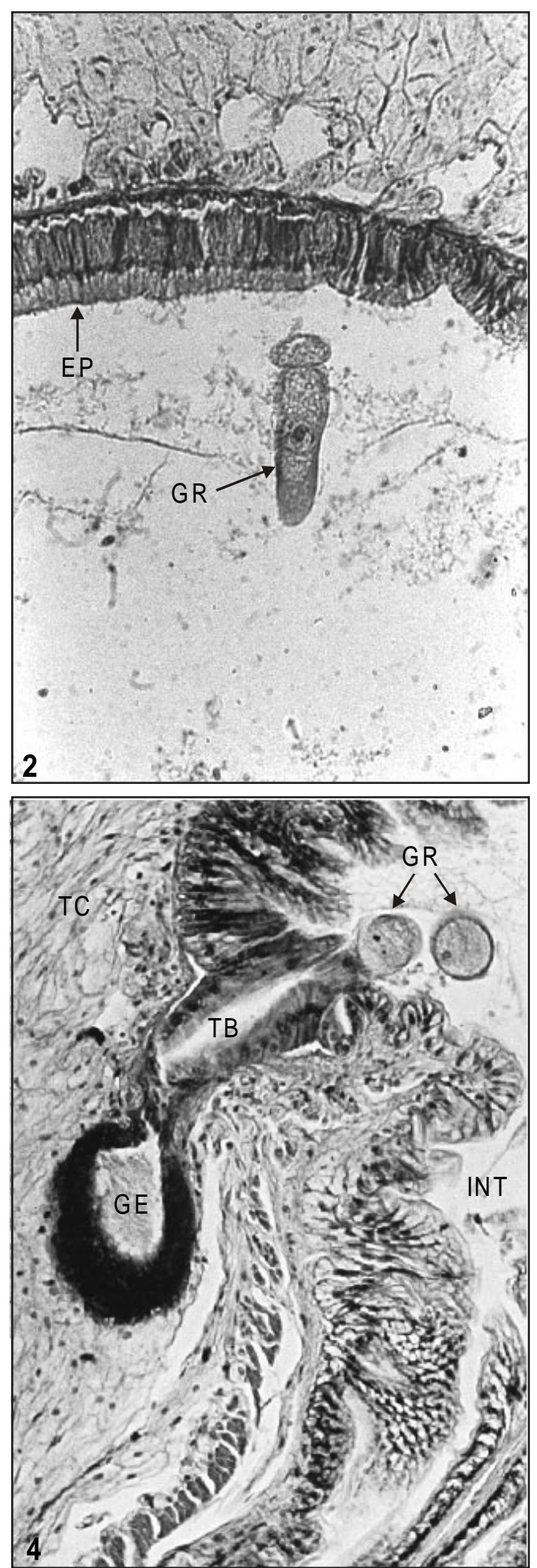

Intestine of Euraphia rhyzophorae midgut. Fig. 1: GR: gregarines in syzygy; INT: intestine; NU: nucleus; MR: stock material, TC: connective tissue. Gallocyanin and Chromotop 2R. 250x. Fig. 2: intestinal epithelium (EP). Gallocyanin and Eosin. 250x. Fig. 3: EP; ESP: spores inside intestine cells; VC: hyalin vacuoles and dark spores. Heidenhain's Iron Hematoxylin. 250x. Fig. 4: GR in pancreatic secretion. TB: conducting tube of pancreatic secretion; GE: pancreatic gland. Gallocyanin and Chromotrop 2R. 250x. 
a central nucleus, round and rich in chromatin. Within the cytoplasm clear vacuoles are seen (Fig. 3, VC). These contain one or more sporocysts measuring about $40 \mu \mathrm{m}$ which stand out as dark bodies in the hyaline vacuoles (ESP). They emerge into the lumen throughout the entire intestine.
These gregarines of rounded forms (Fig. 4, GR) emerge from the duct (TB) of the pancreatic gland (GE). This picture shows where the duct of the pancreatic gland comes in contact with the epithelium of the intestine and two spherical gregarines. Some gregarines (Fig. 5, GR) are seen in the intestinal folds (DB). Others appear to be passing
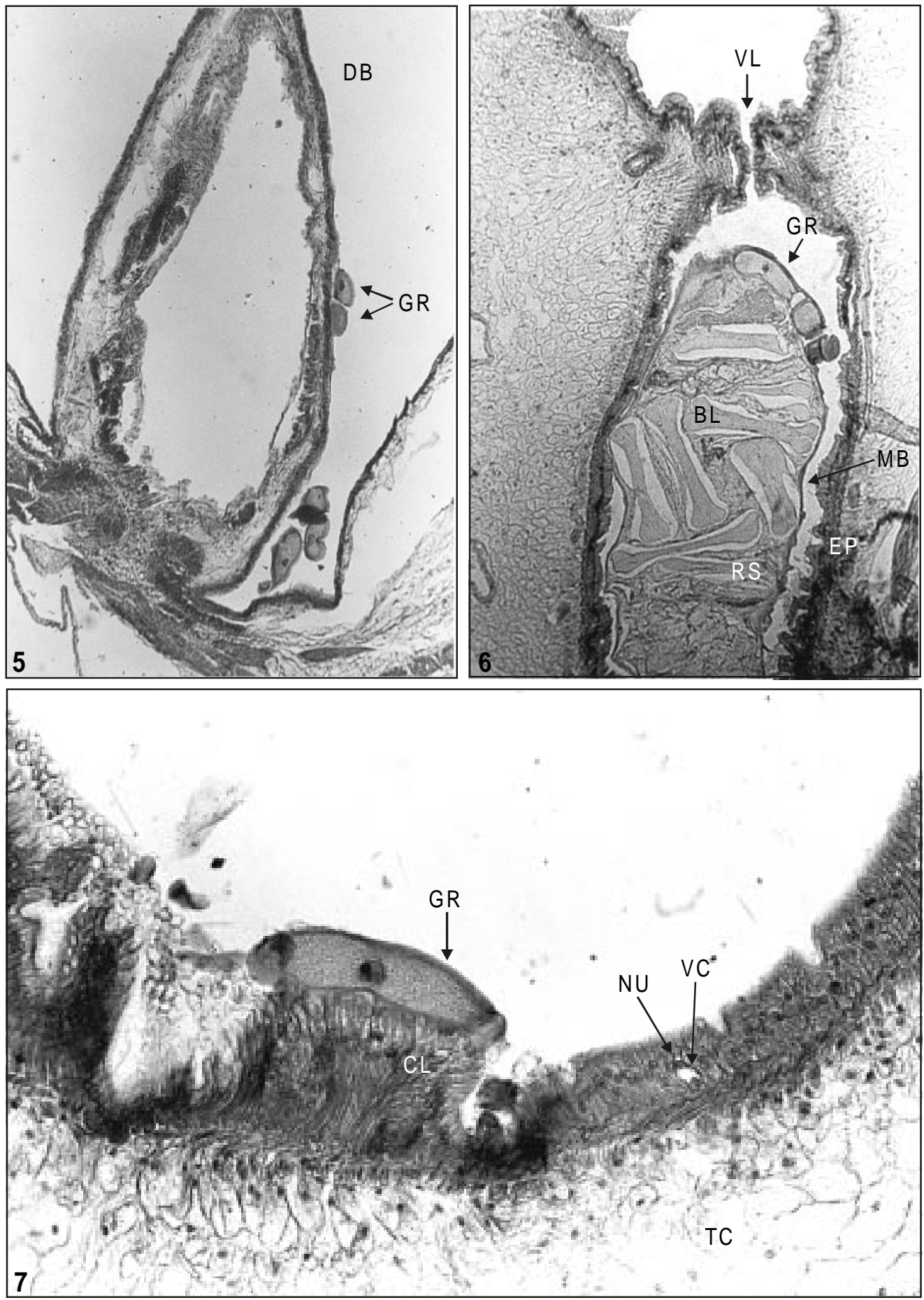

Fig. 5: internal fold of intestinal epithelium. Gregarines (GR) near the intestinal fold; DB: intestine fold. Gallocyanin and Eosin. 100x. Fig. 6: hind region of intestine. BL: fecal mass; MB: limiting membrane of fecal mass; RS: fecal remainder; EP: intestinal epithelium; VL: limiting valve of estomodeo with proctodeo. Heidenhain's Iron Hematoxylin. 100x. Fig. 7: the relation GR and epithelial cell CL. NU: nucleus; VC: vacuole; TC: connective tissue. Gallocyanin and Chromotrop 2R. 250x. 
from the midgut into the proctodeum, remaining in the posterior intestine close to the fecal mass (Fig. 6, BL). In this longitudinal section one sees the sphincter (VL) that separates the midgut from the posterior intestine.

Fig. 7 shows a giant gregarine (GR), about $150 \mu \mathrm{m}$ long, close to a row of epithelial cells. In the mid part of the deutomerite (Fig. 8, DT) there is a disctinct nucleus $(\mathrm{NU})$, spherical, poor in chromatin (CR) but with an accentuated nuclear membrane. A dense nucleolus (NUC) is present. The cytoplasm is granular (CT), almost alveolar but it may also show dark spots, as in Fig. 1 (MR).

Some gregarines present matching posterior parts, familiar figures of syzygy, as can be seen in Figs 2 and 8 .

The gut parts of E. rhyzophorae, can be observed in Fig. 9, where within the enteron (ENT) a round gregarine (GR), the esophagean valve (VL), a part of the esophagus (ES) and the pharynx (FA), which constitutes the foregut are detected; the pancreatic gland (GE) is always lateral to the intestinal wall.

C. communis found in the barnacles E. rhyzophorae in Brazil may be another giant gregarine like Porospora giganteal and Didymophyes gigantea that parasitizes coleopterans larva (Grassé 1953). In barnacles there was no evidence of cellular damage associated with the presence of these gregarines.

\section{ACKNOWLEDGMENT}

To Genilton Vieira and collaborators of the Laboratory of Production and Handling of Images of the Instituto Oswaldo Cruz-Fiocruz, for assistance in figures reproduction.

\section{REFERENCES}

Arvy L, Nigrelli R 1969. Studies on the biology of barnacles: parasites of Balanus eburneus and Balanus balanoides from New York Harbor and a review of the parasitic diseases of other Cirripedia. Zool New York Zool Society 54: 95-102.

Ball GH 1973. The life histories of some gregarines parasitic in marine Crustacea. J Parasitol 23: 533-534.

Barnes H 1953. An effect of parasitism on Balanus balanus (L) da Costa. Nature 172: 128.

Barth R 1953. Métodos de trabalho na anatomia e histologia entomológica. Mem Inst Oswaldo Cruz 51: 95-139.

Grassé PP 1953. Traité de Zoologie. Anatomie, Systématique, Biologie, Tomo I, Fasc II, Masson, Paris, p. 550-690.

Henry DP 1938. Gregarines of the barnacles from Puget Sound and adjacent areas. Arch Protistenk 90: 414-431.

Kamm MW 1922. Studies on gregarines. Synopsis of the polycystid gregarines of the world. Illinois Biol Monog 7: $1-104$.

Kölliker A 1848. Beiträge zur Kenntnis niederer Tiere. Z Zool 1: 1-37.

Levine ND 1970. Taxonomy of the Sporozoa. Parasitology 56: 208-209.

Mawrodiadi P 1908. Les balanes de la Mer Noire et les grégarines, leurs parasites. Note preliminaire (en russe). Mem Soc Nat Nouvelles Odessa 32: 101-132.

Oliveira LPH 1940. Sobre uma nova espécie de crustáceo Chthamalus rhyzophorae. Mem Inst Oswaldo Cruz 35: 379380.

Pantin CFA 1948. Notes on Microscopical Technique for Zoologists, Cambridge University Press, England, 77 pp.

Pearse AGE 1960. Histochemistry Theoretical and Applied, Churchill Ltd, London, 998 pp.
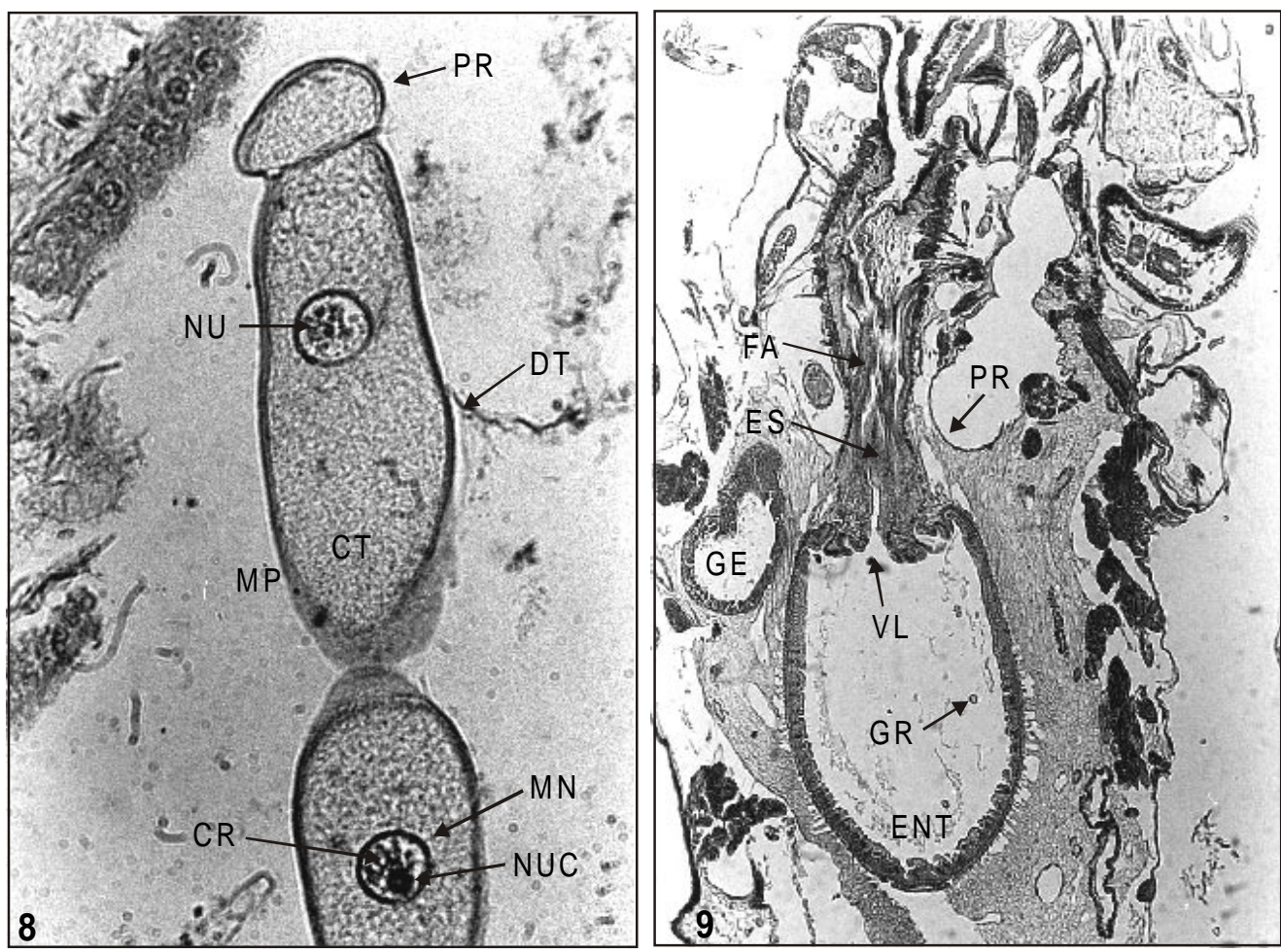

Fig. 8: gregarines in syzygy. PR: protomerito; DT: deutomerito; NU: nucleus; NUC: nucleolus; MN: nuclear membrane; CR: chromatin: MP: plasma membrane; CT: granular cytoplasm. Gallocyanin and Chromotrop 2R. 450x. Fig. 9: longitudinal histological section of the anterior digestive tube of Euraphia rhyzophorae. PR: proctodeo region; ENT: enteron; VL: retention valve of food from proctodeo to enteron; GR: spheric gregarine in the enteron; GE: pancreatic gland; ES: esophagus; FA: pharynx. Mallory's Hematoxylin. 100x. 
Pinto C 1919. Contribuição ao Estudo das Gregarinas, Thesis, Instituto Oswaldo Cruz, 113 pp.

Reger JF 1966. The fine structure of membrane specializations in a gregarine parasitic in the barnacle Balanus tintinnabulum. J Cell Biol 31: 134A.

Reger JF, Barnett A, Roger MP 1967. Observations on an unusual membrane complex found in gregarine parasitic in the barnacle Balanus tintinnabulum. J Vetrast Res 18: 422-427.

Romein B 1928. Guia Formulário de Técnicas Histológicas, Barcelona, Madrid 722 pp.

Tregouboff G 1912. Sur les grégarines des balanes. Arch Zool
Exp 3: 53-61.

Tuzet O, Ormières R 1964. Sur Cephaloidophora communis Mawrodiadi 1908, Pyxinioides chthamali Lég. Dub. 1909 et Bifilida rara n.g.n.sp. Eugrégarines parasites de Cirripèdes. Leurs sporocystes. Arch Zool Exp Gen 104: 153-161.

Vivier E, Desportes I 1989. Phylum Apicomplexa. Chapter 30. In Handbook of Protoctista. The Structures, Cultivation, Habitats and Life Histories of the Eukaryotic Microorganisms and their Descendants Exclusive of Animals, Plants and Fungi, Jones and Bartlett, Boston, p. 549-573. 
1062 Gregarines in Barnacles from Brazil - Dyrce Lacombe et al. 